OPEN ACCESS

Edited by:

Vijai Kumar Gupta,

National University of Ireland, Galway,

Ireland

Reviewed by:

Akanksha Singh,

Central Institute of Medicinal

and Aromatic Plants, India

Ravindra Nath Kharwar,

Banaras Hindu University, India

*Correspondence:

Choong $\mathrm{H}$. Lee

chlee123@konkuk.ac.kr

Specialty section: This article was submitted to Fungi and Their Interactions,

a section of the journal

Frontiers in Microbiology

Received: 11 August 2016

Accepted: 07 October 2016

Published: 19 October 2016

Citation:

Singh D, Son SY and Lee CH (2016)

Perplexing Metabolomes in Fungal-Insect Trophic Interactions: A Terra Incognita of Mycobiocontrol

Mechanisms.

Front. Microbiol. 7:1678.

doi: 10.3389/fmicb.2016.01678

\section{Perplexing Metabolomes in Fungal-Insect Trophic Interactions: A Terra Incognita of Mycobiocontrol Mechanisms}

\author{
Digar Singh, Su Y. Son and Choong H. Lee* \\ Department of Bioscience and Biotechnology, Konkuk University, Seoul, South Korea
}

The trophic interactions of entomopathogenic fungi in different ecological niches viz., soil, plants, or insect themselves are effectively regulated by their maneuvered metabolomes and the plethora of metabotypes. In this article, we discuss a holistic framework of co-evolutionary metabolomes and metabotypes to model the interactions of biocontrol fungi especially with mycosed insects. Conventionally, the studies involving fungal biocontrol mechanisms are reported in the context of much aggrandized fungal entomotoxins while the adaptive response mechanisms of host insects are relatively overlooked. The present review asserts that the selective pressure exerted among the competing or interacting species drives alterations in their overall metabolomes which ultimately implicates in corresponding metabotypes. Quintessentially, metabolomics offers a most generic and tractable model to assess the fungal-insect antagonism in terms of interaction biomarkers, biosynthetic pathway plasticity, and their coevolutionary defense. The fungi chiefly rely on a battery of entomotoxins viz., secondary metabolites falling in the categories of NRP's (non-ribosomal peptides), PK's (polyketides), lysine derive alkaloids, and terpenoids. On the contrary, insects overcome mycosis through employing different layers of immunity manifested as altered metabotypes (phenoloxidase activity) and overall metabolomes viz., carbohydrates, lipids, fatty acids, amino acids, and eicosanoids. Here, we discuss the recent findings within conventional premise of fungal entomotoxicity and the evolution of truculent immune response among host insect. The metabolomic frameworks for fungal-insect interaction can potentially transmogrify our current comprehensions of biocontrol mechanisms to develop the hypervirulent biocontrol strains with least environmental concerns. Moreover, the interaction metabolomics (interactome) in complementation with other -omics cascades could further be applied to address the fundamental bottlenecks of adaptive co-evolution among biological species.

Keywords: fungal interactions, entomotoxins, insect defense, metabolomes, metabotypes

\section{INTRODUCTION}

The kingdom of fungi has undergone critical metabolic advancements in defining its ecological interactions as an antagonistic or ammensalic, a commensalic, and a parasitic partner (Box 1) (Kempken and Rohlfs, 2010). The Inter- and intra- specific interactions in nature under the influence of various environmental factors are mediated through an array of metabotypes 
BOX 1| Glossary.

Antagonistic interactions: the biotic interactions in ecosystem where one species is benefited at the cost of another interacting species. The antagonistic interactions are variously manifested as parasitism, predation, or antibiosis.

Ammensalism: ecological interaction between the organism of different species where one organism is inhibited or destroyed while the other remains unaffected. Commensalism: the interaction among the members of two different species where one species is selectively benefitted whereas another one remains unaffected. Interactome: the whole set of molecular interactions among the nucleic acids, proteins, or metabolites in a cell, tissue, organ, or an organism. The term is generally applied to the intra- or inter-molecular interaction of protein or proteinaceous entities.

Metabolomes: the collection of gross metabolites representing the current physiological state of an organism.

Metabolomics: it refers to the discipline involving the global evaluation of biochemical events in terms of the metabolite cues representing a particular physiological state of a cell, tissue, organ, or an organism.

Metabotypes: the metabolic phenotypes expressed or observed externally in response to intrinsic or environmental stimuli indicating a particular physiological state of an organism.

Trophic interactions: interaction among the organism at different levels of the food chain or food web.

or metabolic phenotypes. These metabotypes, specifically the secondary metabolites, develop during the courses of ecological interactions of fungi and primarily belongs to polyketide, non-ribosomal peptides (NRP's), alkaloid (lysine derived), and terpenoid classes (Sheridan et al., 2015). Biochemically, we can define these metabolic entities as "a heterogeneous class of low molecular weight compounds that, unlike primary metabolites, are not essential for the vital life functions i.e., growth or reproduction. However, these metabolites are extremely active at significantly low concentrations, and, can distinctly function as means of chemical communication or any sort of ecological interaction between fungi and its partners under a variety of environmental conditions (Karlovsky, 2008; Wiemann and Keller, 2014). Hence, an insight of the esoteric dynamic interplay of metabolic phenotypes and overall metabolomes under the ecological interface of fungal-insect interactions can provide an impetus to the ongoing efforts of developing the hypervirulent biocontrol strains with applications in sustainable agriculture, environment, and health through curbing the pestborne diseases.

Entomopathogenic fungi with nearly 750 species and 90 genera constitute the largest group of natural enemies to the pest insects nuisance to mankind in different ways. Most of the species from the classes, Zygomycetes and Ascomycetes, and Division - Amastigomycota, are known to be entomoparasitic (Roberts et al., 1991; Hajek, 1997; Roy et al., 2006; Molnár et al., 2010; Vega et al., 2012). Commercially, about 170 pest control agents are developed and marketed so far based on the 12 different entomopathogenic fungal species (de Faria and Wraight, 2007). The most pronounced species viz., Metarhizum anisopliae (Metsch.) Sorokin, Beauveria bassiana, Vullemin, Isaria fumosorosea, and B. brongniartii etc. (de Carolina Sánchez-Pérez et al., 2014), are well documented for the production of enzymes as well as chemically diverse and biologically potent entomotoxic metabolites.

\section{ENTOMOPATHOGENIC FUNGI: DISTRIBUTIONS}

The entomopathogenic fungi, being the natural enemies to the umpteen varieties of insect and arachnid species exhibits a proportional cosmopolitan distribution. The entomopathogenic fungi are distributed to a myriad of habitats viz., soil, above or below ground plant parts, and host insect themselves in both aquatic as well as terrestrial environments.

\section{Soil}

The soil being one of the most diverse environments for microbiological entities serves as the natural home for entomopathogenic fungal species. The different classes of biocontrol fungi have been documented from the soil (Keller et al., 2003; Meyling and Eilenberg, 2006). Functionally, the soil provides nutrients besides protection from the aerial anomalies like dehydration and harmful radiations. Soil usually shelters the fungal microflora under the suitable conditions of $\mathrm{pH}$, humidity, and temperature (Keller and Zimmermann, 1989). The various soil conditions which primarily govern the distribution and density of entomopathogenic fungi includes geographical locations, climatic conditions, habitat type, cropping system, soil properties, and the numerous biotic as well as abiotic factors (Quesada-Moraga et al., 2007). The Inter- and intra-species chemical ecology of fungi is mainly regulated by accessibility to the nutrients and space, which governs their successful infection in host. The expression of fungal toxins and metabolites increase their ecological competitiveness to infect the corresponding host. The secretion of mycotoxin, zearalenone by Fusarium spp. helps the fungus to suppress the growth of competing species, and hence best reserve its host colonization conditions (Utermark and Karlovsky, 2007). The most renowned of the species includes, Trichoderma which produces a variety enzyme toxins viz., chitinases, glucanases, and proteases, all together helps it to compete best over their rival and host species making it most ubiquitous fungi in nature (Benítez et al., 2010). Moreover, a plethora of insects or plant hosts available in soil serves as the source of potential nutrients for fungi (Vega et al., 2009). Hence, soil ecosystem represents an amenable environment which facilitates the fungal species to fulfill its important ecological functions related with host mycoses and nutrition.

\section{Plants}

A large number of biocontrol fungi are reportedly harbored by plants as endophytes or epiphytes (Arnold and Lewis, 2005). Here exist the synergistic interactions between the host plant and the fungi, which provide a defense shield to the host 
through its chemical weaponry of entomotoxic metabolites (Alabouvette et al., 2009). Plant-associated fungi are functionally classified as mycorrhizal, pathogenic, epiphytic, endophytic, and saprotrophic fungi (Porras-Alfaro and Bayman, 2011). The plant associated fungal species influence the chemical ecology of host plants toward the various biotic and abiotic stresses through either of the interactions viz., antagonism, parasitism, or mutualism effecting direct production of functional or elicitor metabolites. The most significant and well studied mechanism is the induction of "systemic acquired resistance (SAR)" mediated by plant stress metabolites viz., salicylic acid, jasmonic acid, ethylene, and a variety of pathogenesis-related (PR) proteins (Tripathi et al., 2008). The latent infection of maize varieties by $F$. verticillioides, producing mycotoxins viz., fumonisins, fusarins, and fusaric acids often positively regulates the yield and vegetative growth of the host plant. However, the increased production of fumonisin, owing to the altered abiotic or biotic conditions seldom cause infection of maize kernels resulting in the "ear-rot" disease in host (Glenn et al., 2008). The similar examples may include the species of Beauveria, Lecanicillium, and Trichoderma, which are best characterized to induce SAR in their respective host plants (Ownley et al., 2009).

\section{Host Insects}

The entomopathogenic fungi enter and infect their target host through direct contact, making the former a more successful insecticide than their bacterial counterparts. The development of infection stages through conidia adhesion, penetration of insect cuticle by appresoria, and subsequent mycelia development are mediated through a range of hydrolytic enzymes viz., proteases, chitinases, lipases, and lipoxygenases (de Carolina SánchezPérez et al., 2014). Once entered the insect host, the fungal mycelia grows as naked yeast-like propagules (blastospores), mechanically damaging the haemocoel and subsequently release a battery of entomotoxic metabolites. Although, the trophic interactions among the species are influenced by an infinite number of parameters of both biotic and abiotic origins, we would like to construe our interpretations in terms of the selected sets of metabotypes and altered metabolomes in fungal-insect antagonistic trophic interface (Box 1). The theoretical model of the present section of the review can best be visualized in Darwin's famous exposition;

"It follows that any being, if it vary, however, slightly in any manner profitable to itself, under the complex and sometimes varying conditions of life, will have a better chance of surviving, and thus be naturally selected."

(Chapter III - Struggle for existence, Origin of Species, Charles Darwin)

The majority of the well characterized insect associated fungi belongs to the order Entomophthorales (Phylum: Glomeromycota) and order Hypocreales (Phylum: Ascomycota), existing in both or either of their sexual (telomorph) or asexual (anamorph) phases of life cycle. The most significant of the insect associated fungi are isolated as anamorphs of the genus 'Cordyceps' viz., Beauveria, Lecanicillium, and Isaria (Blackwell, 2010). The commercial strains of Metarhizium and Beauveria are alone known to infect more than 200 species of different insect pests responsible for agricultural havocs (Toledo et al., 2008). The in vivo interactions between the entomopathogenic fungi and their insect host are antagonistic in nature, with hyperparasitic efficacy (Zimmermann, 2007; Vega et al., 2009). Here, both the pathogen (fungi) and the host (insect) evolves simultaneously in multiple dimensions viz., behaviorally, physiologically, ecologically, and metabolically to attain the necessary fitness to survive (Roy et al., 2006). These bizarre ecological relations are maintained with the help of a highly evolved biosynthetic machinery to produce the necessary mycotoxins which defines the trophic interactions of all entomopathogenic fungi. The chemistry of fungal interactions with insects is governed by a spectrum of cryptic metabolites falling into four major classes' viz., NRP's, alkaloids, terpenes, and polyketides (Rohlfs and Churchill, 2011). The major genera of domesticated entomopathogenic fungi (shown here using the classification system proposed by Alexopoulos and Mims, 1979), their insect host, related toxic metabolites, and commercial adaptations are summarized in Table 1.

\section{ANTAGONISTIC METABOLOMES: FUNGAL-INSECT TROPHIC INTERACTIONS}

The active production of induced defense metabolites serves as a key defense mechanism against host insect's counter immunity. Analogous antagonistic defense mechanisms are very common in plants, but are largely unexplored among fungi and their insect hosts. Here, we discuss the entomopathogenic fungi as the study model among their fungal counterparts. Most notable genera are the Metarhizium, Beauveria, and Aspergilli etc. which relies upon the polyketides, alkaloids, and NRP's (non-ribosomal peptides) as their chemical shield or offensive tools of metabolites (Rohlfs and Obmann, 2009; Döll et al., 2013; Singh and Kaur, 2014a). Further, the in vivo expression of the toxin metabolite types and their relative quantities depends upon the respective insect host and numerous other factors (Skrobek et al., 2008). Either induced or intrinsic, expression of defense metabolites among the antagonistically interacting species triggers a state of metabolic plasticity.

\section{Fungal Metabotypes and Their Entomotoxicity Mechanisms}

The expression of metabolic phenotypes in fungi is a highly stringent process governed by the forces of natural selection ensuring its survival under altered ecological conditions. Although not necessary toward the major functions of growth and reproduction, secondary metabolites enable the fungi to survive and compete in an ecologically challenging environment viz., the presence of competing microorganisms, nutrient limitation, and protection against insect's fungivory or evasion of host's immune system (Wiemann and Keller, 2014). The fungal interactions with host insects drive their biosynthetic machinery to undergo altered metabolic states which we have envisaged using the Kyoto encyclopedia of genes and genomes (KEGG) pathway maps (Kanehisa and Goto, 2000), in Figure 1. Below, we 
TABLE 1 | The major fungal divisions with entomopathogenic members, entomotoxic metabolites, and host insect range.

\begin{tabular}{|c|c|c|c|c|}
\hline $\begin{array}{l}\text { Taxonomic } \\
\text { ranks } \downarrow\end{array}$ & Entomotoxic metabolites & Host & Commercial formulations & Reference \\
\hline \multicolumn{5}{|c|}{ Division: Amastigomycota (Non-flagellated terrestrial fungi) } \\
\hline \multicolumn{5}{|c|}{ Subdivisions: **Ascomycotina (Telomorphs) and *Deuteromycotina (Anamorphs) } \\
\hline \multicolumn{5}{|l|}{ Genera } \\
\hline Cordyceps** & Cordycepins & Lepidopteran larvae & - & $\begin{array}{l}\text { Kim et al., 2002; Kryukov et al., } \\
2014\end{array}$ \\
\hline $\begin{array}{l}\text { Hypocrella**/ } \\
\text { Aschersonia* }\end{array}$ & $\begin{array}{l}\text { Ergosterol, Dustanin, } \\
\text { Hypocrellins, } \\
\text { 3-hopane-triterpenes }\end{array}$ & $\begin{array}{l}\text { Aleyrodidae, Coccidae families of } \\
\text { Hemiptera, and Nematodes }\end{array}$ & - & $\begin{array}{l}\text { Isaka et al., 2003; Jin-Ming, 2006; } \\
\text { Buttachon et al., } 2013\end{array}$ \\
\hline Beauveria* & $\begin{array}{l}\text { Beauvericin, Bassianin, } \\
\text { Oosporein, and bassianolide }\end{array}$ & $\begin{array}{l}\text { Lepidoptera, Coleoptera, Hemiptera, } \\
\text { Homoptera, and Hymenoptera }\end{array}$ & $\begin{array}{l}\text { Naturalis }^{\mathrm{TM}} \text {, Botanigard } \\
\text { Mycotrol } \mathrm{O}^{\mathrm{TM}} \text {, and } \\
\text { Byeverol, } \\
\text { Brocaril, Ostrinil }\end{array}$ & $\begin{array}{l}\text { Elsworth and Grove, 1977; Uma } \\
\text { Devi et al., } 2008\end{array}$ \\
\hline Metarhizium* & Swainsonine, and Destruxins & $\begin{array}{l}\text { Coleoptera, Hemiptera, Isoptera, } \\
\text { Homoptera, Heteroptera, Diptera } \\
\text { (Mosquitoes), Hymenoptera, } \\
\text { Siphonaptera and Lepidoptera }\end{array}$ & $\begin{array}{l}\text { MET52 }^{\mathrm{TM}} \text {, Bioblast } \\
\text { BioPath } \\
\text { BM } \\
\text { and Green Muscle }\end{array}$ & $\begin{array}{l}\text { Goettel et al., 2001; Quarles, 2013; } \\
\text { Singh and Kaur, 2014a }\end{array}$ \\
\hline $\begin{array}{l}\text { Paecilomyces* } \\
\text { (Isaria) }\end{array}$ & $\begin{array}{l}\text { Beauvericin, Beauverolides, } \\
\text { and Dipcolonic acid (DPA) }\end{array}$ & Hemiptera & PFR-97, PreFeRal, and Pae-Sin & Vey et al., 2001 \\
\hline Verticillium* & $\begin{array}{l}\text { hydroxycarboxylic acid, } \\
\text { cyclosporine, and Dipicolonic } \\
\text { acid, Bassianolide }\end{array}$ & Hemiptera and Thysanoptera (thrips) & $\begin{array}{l}\text { Mycotal, Vertalec, and } \\
\text { Bio-Catch }\end{array}$ & Vey et al., 2001 \\
\hline Tolypocladium* & $\begin{array}{l}\text { Efrapeptins, Tolypin, } \\
\text { Diketopiperazines }\end{array}$ & $\begin{array}{l}\text { Diptera (Mosquitoes), Ephemeroptera } \\
\text { (Mayflies) }\end{array}$ & - & Bandani, 2004; Bandani, 2008 \\
\hline Hirsutella & Hirsutellin A and B & $\begin{array}{l}\text { Mites (Citrus rust mites- Phyllocoptruta } \\
\text { oleivora), Lepidotera (Galleria melonella) }\end{array}$ & Mycar & $\begin{array}{l}\text { McCoy et al., 1992; Aghajanzadeh } \\
\text { et al., } 2006\end{array}$ \\
\hline $\begin{array}{l}\text { Nomuraea rileyi* } \\
\text { (Cordycep*) }\end{array}$ & Ergosterol peroxide & Lepidoptera, Coleoptera, Hemiptera & $\begin{array}{l}\text { AGO biocontrol nomuraea 50, } \\
\text { PreFeRal }\end{array}$ & $\begin{array}{l}\text { Prompiboon et al., 2008; Onofre } \\
\text { et al., } 2002\end{array}$ \\
\hline Torrubiella & Torrubiellin B (2) & Hemiptera (Coccoidea) & - & Isaka et al., 2012 \\
\hline
\end{tabular}

Subdivision: Basidiomycotina

Genera

Septobasidium

- Hemipteran scale insects -

Hemipteran scale insects -

Delicately mutualistic (often

Hudson, 1986 detrimental to insect spp.)

Subdivision: Zygomycotina - specifically describing the newly classified members under the subdivision 'Entomophthoromycotina' as described by Humber (2012).

\begin{tabular}{|c|c|c|c|c|}
\hline \multicolumn{5}{|l|}{ Genera } \\
\hline Erynia & - & Hemiptera (aphids) & - & Milner, 1997; Pell et al., 2001 \\
\hline Zoophthora & - & $\begin{array}{l}\text { Coleoptera, Diptera, Hemiptera, } \\
\text { Hymenoptera, Lepidoptera, Orthoptera, } \\
\text { Trichoptera }\end{array}$ & - & $\begin{array}{l}\text { Glare and Milner, 1991; Pell et al., } \\
2001\end{array}$ \\
\hline \multicolumn{5}{|c|}{ Subdivision: Haplomastigomycotina } \\
\hline Coelomycidium* & - & Dipterans (specially black flies) & - & Kim, 2011 \\
\hline Myiophagus & - & Dipterans & - & $\begin{array}{l}\text { Karling, 1948; Araújo and Hughes } \\
2016\end{array}$ \\
\hline Leptogenia & - & Dipterans (mosquito larvicidal) & - & $\begin{array}{l}\text { Lastra et al., 2004; Pelizza et al., } \\
\text { 2007, } 2013\end{array}$ \\
\hline Pythium & - & Dipterans (Mosquito larvicidal) & - & Su et al., 2001 \\
\hline
\end{tabular}

The fungal classification system was primarily adapted from Alexopoulos and Mims (1979). 


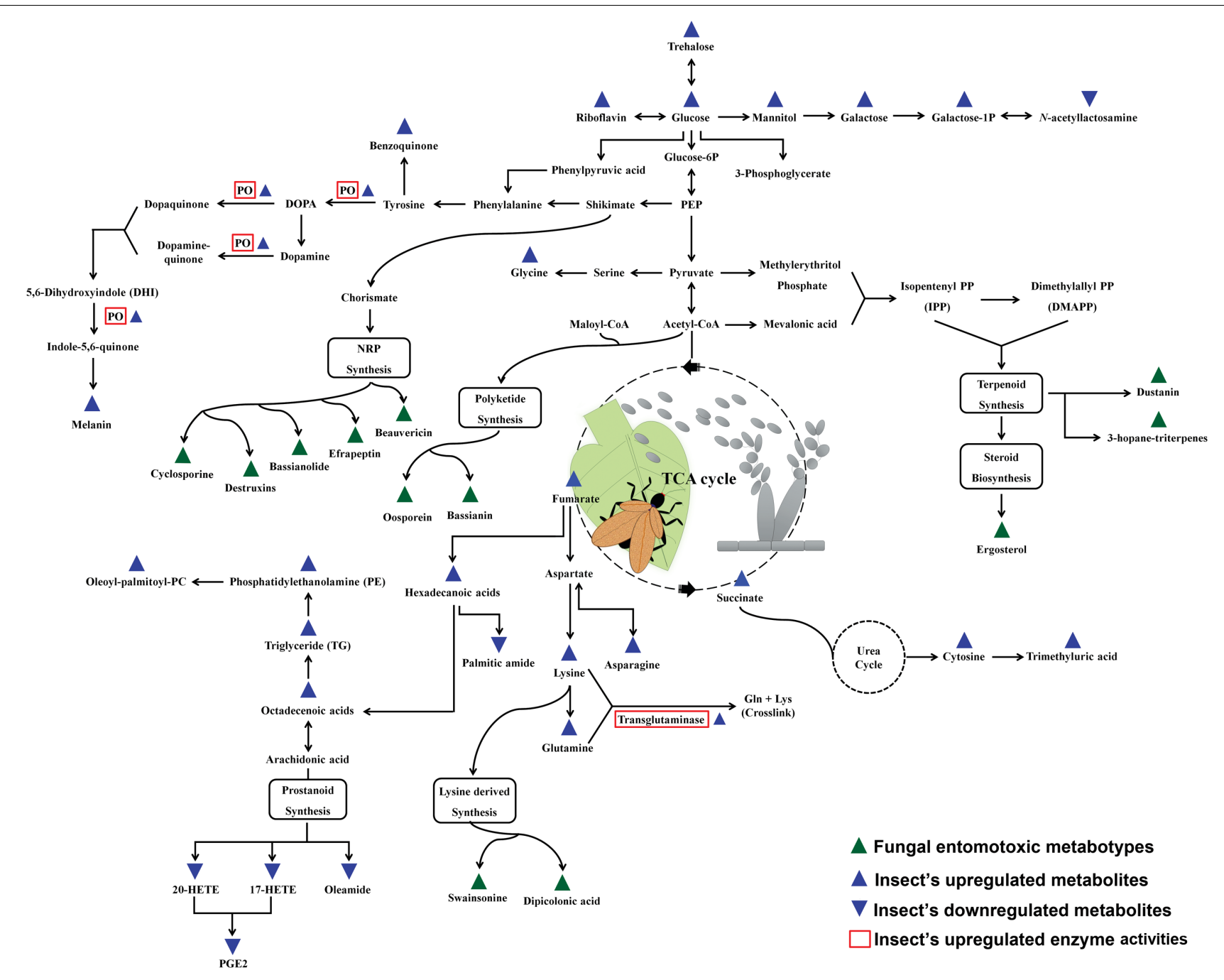

FIGURE 1 | Schematic representation of the fungal metabotypes and altered co-evolutionary insect metabolomes maneuvered during the antagonistic interactions. The scheme of reference metabolic pathways is adapted from the KEGG (Kyoto Encyclopedia of Genes and Genomes) pathway maps.

introduce few of the umpteen metabotypes reportedly expressed during the stages of insect mycoses and briefly discuss their explicit entomotoxic effects. The chemical structures for these toxic fungal metabolites are shown in Figure 2.

\section{Non-Ribosomal Peptide (NRP's) Destruxins}

The destruxins (Dxs) are structurally composed of an alphahydroxy acid and five amino acid residues joined together by amide and ester linkages to form a cyclic structure. There are 38 Destruxins or Dx analogs (Pedras et al., 2002), which is double the earlier reported, 19 types (Gupta et al., 1989). They are divided chemically into five basic groups labeled as A through E, plus several subgroups of each. Destruxins A and B were first reported in the Metarhizium isolates from Japan during 1960's and were synonymously named as "oospora destructor" or destruxins. These cyclic depsipeptides have extensively been studied by plant pathologists, microbiologists, and natural products chemists for their toxic biochemical activities. The Dx - biosynthetic pathway is assumed to be a non-ribosomal multifunctional enzyme system (Kleinkauf and von Döhren, 1987, 1990; Turner, 2000). The insect specific toxicity of Dxs A, B, and E is well documented with reported induction of acute muscular paralysis in arthropods through the reversible opening of their muscle cell membrane $\mathrm{Ca}^{+2}$ channels (Samuels et al., 1988; Dumas et al., 1996). The ionophoric properties of Dx A also allow $\mathrm{Ca}^{+2}$ mobilizations across liposomal membrane barriers (Hinaje et al., 2002). Alternatively, Dxs are also reported to cause the inhibition of vacuolar (V-type) ATPase activity in the brush bordered midgut (BBM) membrane of Galleria mellonella, however, its structural stability is significantly compromised under the altered physiological conditions inside the host (Bandani et al., 2001). The Dx variants are further known for triggering the oxidative stress mechanisms in host (Spodoptera litura) through up regulating the levels of superoxide radicals and the systemic suppression of insect immunity (Pal et al., 2007; Sowjanya Sree 


\section{Non-ribosomal peptides}
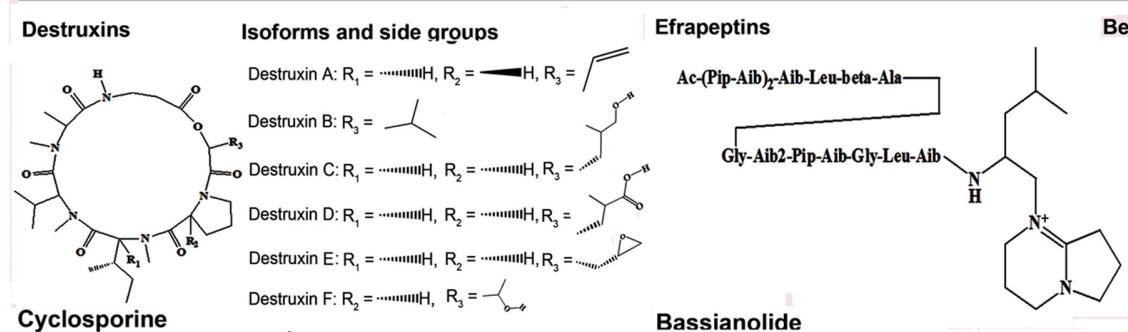

Cyclosporine Destruxin $F: R_{2}=\cdots \cdots \cdots+\cdots, R_{3}=\chi_{0}$

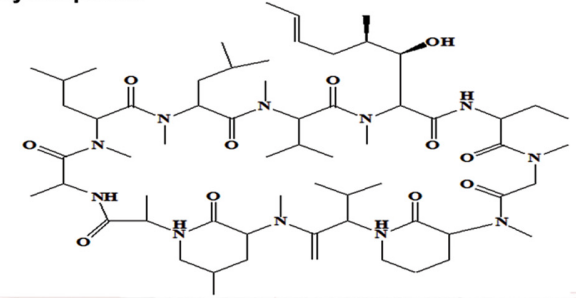

Bassianolide

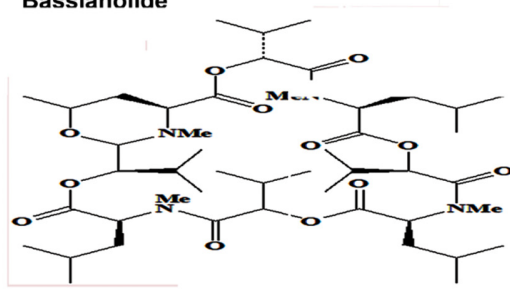

Beauvericin

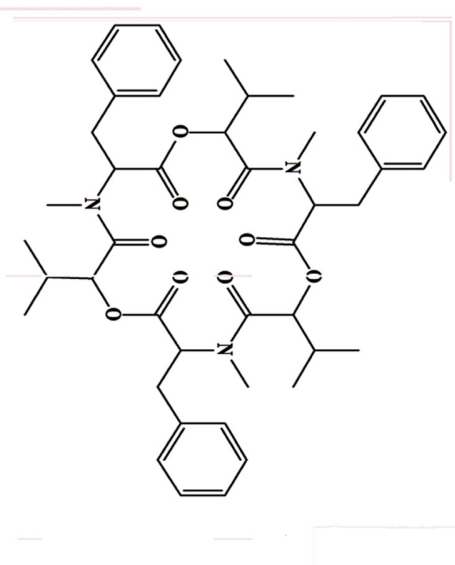

\section{Polyketides}<smiles>CC1=C(O)C(=O)C(C2=C(O)C(=O)C(O)=C(O)C2=O)=C(O)C1=O</smiles>

\section{Lysine derived}

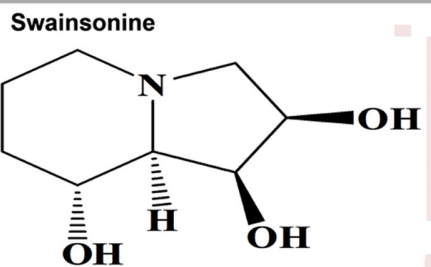

\section{Terpenoids and Steroids}

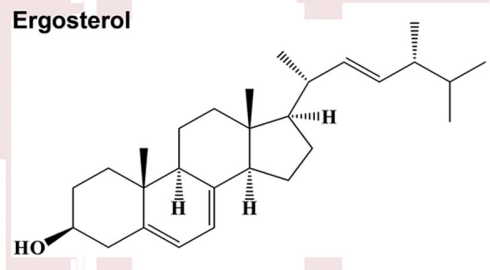<smiles></smiles><smiles>O=C(O)c1cccc(C(=O)O)n1</smiles>
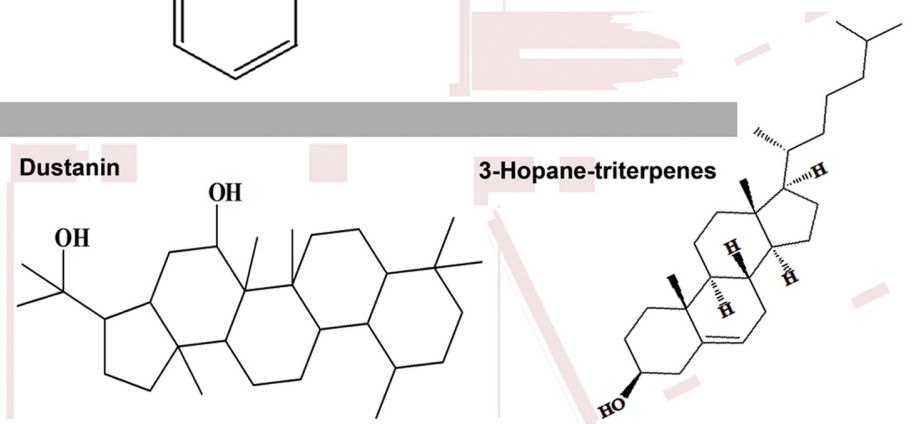

FIGURE 2 | Different entomotoxin structures and their respective biosynthetic classes in entomopathogenic fungi.

et al., 2008). More recently, Meng et al. (2013) have described a yet another toxicity mechanism for Dx A on Spodoptera litura with deleterious effects on its wing disc like proteins (SLAWD) expressions, hence inducing the developmental abnormalities in larval stages of development.

\section{Efrapeptins}

These are the complex mixture of peptide toxins reported from the entomopathogenic soil hyphomycetes fungi, Tolypocladium spp. (Gupta et al., 1992). The variant form, Efrapeptin $\mathrm{F}$ is also known to significantly inhibit the activity of V-type ATPases, which regulates the protons gradient $\left(\mathrm{K}^{+} / \mathrm{H}^{+}\right)$across the brush bordered epithelium in insect mid-gut (Bandani et al., 2001). Simultaneously, the toxin has been reported to adversely affect the cell mediated immune mechanism in the host insect G. mellonella (Bandani, 2008).

\section{Beauvericin}

It's an ionophoric cyclohexadepsipeptide of enniatin antibiotic family which can permeate through biological membranes 
with enhanced entomotoxic activities (Gupta et al., 1991). Structurally, a beauvericin molecule is consists of the alternating amino acid units of the three D-hydroxyisovaleryl and three N-methylphenylalanyl residues (Hamill et al., 1969). The compound was first isolated from B. bassiana, but was later reported from Fusarium, Verticillium, and Paecilomyces spp. (Suzuki et al., 1977). The various diastereoisomers of beauvericin (A, B, and $\mathrm{C}$ etc.) shows the insecticidal activities against a spectrum of pest species viz., Artemia salina, Calliphora erythrocephala, Aedes aegypti, Lygus, S. frugiperda, and Schizaphis graminum (Grove and Pople, 1980; Jestoi, 2008; Wang and $\mathrm{Xu}, 2012)$. Functionally, the ionophoric nature of beauvericin allows the compound to form reversible complexes with divalent $\left(\mathrm{Ca}^{+2}, \mathrm{Ba}^{+2}\right)$ and monovalent $\left(\mathrm{Na}^{+1}, \mathrm{~K}^{+1}\right)$ ions, which effectively disturb ionic equilibrium and $\mathrm{pH}$ potential across the lipid bilayers resulting in loss of membrane associated functions in insect host cells (Tang et al., 2005; Tonshin et al., 2010).

\section{Bassianolides}

The bassianolides are structurally similar to beauvericin except the alternate four subunit repeats of d-2-hydroxyisovaleric acid (D- $\alpha$-Hiv) and N-methyl Leucine (L-N-Me-Leu) in the cyclooligomer depsipeptide COD making it an octadepsipeptide (Suzuki et al., 1977). As an entomotoxic COD, bassianolide from B. bassiana and V. lecanii is known for inducing acute muscular atony among silkworm larvae through the inhibition of acetyl-choline mediated muscle contractions (Kanaoka et al., 1978; Nakajyo et al., 1983). Few of the reports have suggested the predominant role of bassianolides in fungal virulence as compared to other cyclodepsipeptides i.e., beauvericin, (Champlin and Grula, 1979; Xu et al., 2009). The high efficacy of these compounds as an effective entomotoxin can also be attributed to its structural conformation with hydrophobic exterior and relatively hydrophilic interior making it an ionophoric molecule. A wide range of pest species are reportedly affected through bassianolide exposure viz., Helicoverpa zea (Champlin and Grula, 1979), chagas vector Triatoma infestans (Lobo et al., 2015), and livestock pest Culicoides spp. (Narladkar et al., 2015) etc.

\section{Cyclosporines}

Typically known for their immunosuppressive application for organ transplant, cyclosporines were originally reported from Tolypocladium niveum, and more recently from $T$. inflatum (Weiser and Matha, 1988; Bushley et al., 2013). Specifically, cyclosporine A is known to suppress the insect's humoral or innate immune responses (Fiolka, 2008; Kulkarni et al., 2013). Earlier, the potential suppression of cyclosporine sensitive glycoprotein based efflux pump system in insect cells was recognized as the probable mechanism of insect mycoses (Podsiadlowski et al., 1998). Concomitantly, Fiolka (2008) have further proposed an alternate mechanism of cyclosporine mediated entomoxicity i.e., decrease in the activity of insect's antimicrobial peptides and lysozymes which adversely effects its survival.

\section{Polyketide (PKs) Oosporein}

A non-reduced polyketide commonly reported from Beauveria spp. (Vining et al., 1962; Strasser et al., 2000). Recently, Feng et al. (2015) have verified the role of oosporein (bibenzoquinone oosporein) in establishing the fungal virulence in host insects through the inhibition of insect defense mechanisms viz., PPO (pro-phenoloxidase) activity and down-regulation of antifungal peptide expressions in host.

\section{Bassianin}

It represents a hexaketide compound with a 2-pyridone core reported first from Beauveria spp. and associated with a broad range of biological activities (McInnes et al., 1974). Alternatively, the compound has been reported to inhibit the $\mathrm{Ca}^{+2}$ dependent ATP'ase activities in mammalian erythrocytes (Jeffs and Khachatourians, 1997). However, no elaborated reports are yet available which discuss the specific entomotoxic effects associated with bassianin.

\section{Lysine Derived Swainsonine}

Swainsonine is chemically an indolizidine alkaloid molecule with a fused piperidine and pyrrolidine ring system. This sugar analog was first discovered in Australian native legume Swainsona canescens (Colegate et al., 1979) followed by Astragalus and Oxytropis (Molyneux and James, 1982) as a toxin metabolite responsible for locoweed poisoning among livestock. Later on, the compound was also reported from microbial sources viz., Rhizoctonia leguminicola (Schneider et al., 1983) and M. anisopliae (Hino et al., 1985). Functionally, swainsonine acts as the reversible inhibitor of both lysosomal $\alpha$-mannosidase and mannosidase II enzymes which mainly catalyze the cellular degradation of polysaccharides and asparagine-linked glycoproteins, respectively (Elbein et al., 1981). These properties of swainsonine have been well documented and maneuvered to develop the anti-metastatic and anti-proliferative candidates through laboratory based and clinical trial studies (Sun et al., 2009; Li et al., 2012; Singh and Kaur, 2014b). Although many studies have described the therapeutic potentials of swainsonine, its entomotoxic properties and role in the entomopathogenic virulence of Metarhizium are still largely unexplored. Recently, Singh and Kaur (2014a) have reported the in vitro entomotoxic properties of swainsonine isolated from M. anisopliae against the lepidopteran target host (Spodoptera sp.) through the induction of apoptotic cell death mechanisms. However, the potential role of swainsonine as an entomotoxin for establishing the fungal insect chemical ecology requires further studies.

\section{Dipicolinic Acid}

The potent entomotoxic metabolite is variously been reported from numerous entomopathogenic genera viz., Beauveria, Paecilomyces, and Verticillum (Claydon and Grove, 1982). The pyridine derivative compound i.e., dipicolinic acid (DPA) or pyridine-2, 6-dicarboxylic acid is ubiquitously found in all bacterial spores and confers them thermal resistance (Setlow et al., 2006). In the context of entomotoxicity, the fungal DPA 
or their calcium salts are reportedly known to be active against white fly larvae (Bemisia) and blowflies (C. erythrocephala) with varying degrees of toxicity (Asaff et al., 2005).

\section{Terpenoids and Steroids}

The potent entomotoxic effects for fungal terpenoid and steroid metabolites can be correlated analogously with those of plant steroid where these metabolites serve as juvenile hormones which alter the development and behavior of herbivore insects or seldom induce direct toxicity (Schardl, 2001). The crude extracts from acaricidal fungi Hypocrella raciborskii were characterized for terpenoid and steroid metabolites viz., ergosterol, dustanin and $3 \beta$-acetoxy-15 $\alpha, 22$-dihydroxyhopane (a hopanoid) with varying mechanism of insect deterrence and toxicity (Buttachon et al., 2013). Further, Isaka et al. (2010) have reported the new terpene compounds from entomopathogenic fungi Aschersonia paraphysata with potential in vitro anti-malarial activity for selected hopene metabolites i.e., 17(21)-hopene-6R,12 $\beta$-diol. Hence, one can summarize the antagonistic interactions for terpenoid and steroid class of entomotoxic metabolites which potentially facilitate in insect mycoses or deter the fungivory.

An imponderable number of fungal metabolites acting as entomotoxins ensure their successful ecological succession to overcome the antagonistic arthropod hosts. The fungi, like any other organism are also subjected to the incessant process of natural selection under different environmental conditions including the host's trophic interfaces with antagonistic metabolomes.

\section{INSECT'S CO-EVOLUTIONARY METABOTYPES AND METABOLOME}

The host insects too have developed the competitive coevolutionary defense mechanisms to survive the proportional selection pressure from their respective mycoparasites. The three main lines of insect defense i.e. cuticular, humoral, and cellular responses together resist the entry of fungal pathogens (Dubovskiy et al., 2013). The first and the most vital of the barrier is cuticular, which prevent the entry of fungal infectious forms i.e., conidia or blastospores, releasing a battery of entomotoxic metabolites and hydrolytic enzymes viz., proteases, chitinases, and lipases (Xiao et al., 2012; Ortiz-Urquiza and Keyhani, 2013).

\section{Insect Defense Metabotypes}

Once the fungal appresoria breach through the insect cuticle, the enhanced antiproteolytic and phagocytic activities of insect hemolyph and plasmatocytes, respectively, prevents the further stages of fungal mycoses (Boguś et al., 2007). Besides, the cuticular secretions with fungal enzyme inhibitors and increased phenoloxidase activity (humoral components) are also reported to impede the progression of mycoses (Dubovskiy et al., 2013). However, the role of host insect metabolites is seldom considered important during the different stages of microbial infection and thus remains largely unexplored. Recently, Pedrini et al. (2015) have reported the benzoquinone containing secretions in tenebrionid insects (Tribolium castaneum) as the defensive means against the infestation from entomopathogenic fungi (B. bassiana). The arthropodal quinones can potentially impair the invading pathogens through a number of non-specific defensive phenomena viz., production of ROS (reactive oxygen species) and melanin cross linking of infectious bodies (Nappi et al., 2009). As shown in Figure 1, the phenoloxidase (PO) activities in arthropods effectively maneuvers the phenylalanine (Phe) conversion to tyrosine and a number of biosynthetic pathway intermediates viz., 3,4 dihydroxyphenylalanine (DOPA), Dopamine, and quinone derivatives before finally been converted to melanin compounds (Vilmos and Kurucz, 1998; Fuchs et al., 2014). The upregulation of insect PO activities and melanin biosynthesis effectively cripples the fungal infections inside the host insect through the effective deposition and hardening around the hemocyte encapsulated infectious bodies i.e., blastospores (Smilanich et al., 2009). Hence PO activity simultaneously induced both humoral as well as cellular immune response in arthropods. The melanic strains of G. mellonella (greater wax moth) are known for their heightened resistance to Metarhizium or Beuveria induced mycoses on account of their up-regulated PO activity and thickened deposition of cuticular melanin (Dubovskiy et al., 2013). Hence, the ProPO mediated PO-cascade can undoubtedly be considered as an essential component of insect's innate immunity and thus is tightly regulated by a series of enzyme competitive complexes and signaling pathways i.e., Toll signaling pathways (Kan et al., 2008). Quintessentially, the host-parasite selective co-evolution has resulted in a state of competitive coercion for ecological fitness and survival.

\section{Altered Metabolomes and Insect's Immune Response \\ Carbohydrates, Lipids, and Fatty Acids}

Yet another aspect of insect immunity can be framed using the concept of 'immunity bioenergetics' under the condition of insect mycoses. The estimated cost of immune response in vertebrates is variedly calculated approximately $32 \%$, thus, by analogy, one can assume the respective metabolic expenditures in case of insect mycoses or infections (Martin et al., 2008). The humoral (PO-mediated) and cellular (hemocyte mediated) immunity in infected insects entails bioenergetic cost among the host which can be tracked in its metabolome. A recent progress has led to the identification of the metabolic cues associated with insect's altered metabolomic response to the co-evolutionary selection pressure by entomopathogenic fungi. Xu et al. (2015) have reported the alteration in the levels of energy and nutrient metabolism of silkworm moths infected with B. bassiana. As indicated in Figure 1, the group has observed an upregulation in the levels of carbohydrates, fatty acids, lipids, and amino acids with simultaneous down regulation in eicosanoids and amines. The proposed elevation in the amounts of carbohydrates (sugars) was correlated to the increased ratio of monosaccharide to disaccharide sugars owing to possible bio-conversion to meet the heightened energy cost for immunity and metabolism (Ardia et al., 2012). Another vital component of insect immune response tractable in its metabolome is comprised of lipids, 
fatty acids, and eicosanoids i.e., prostanoids. Intriguingly, the levels of various lipids viz., Phosphatidylethanolamine, triglycerides, glycerophosphocholine, and 1-oleoyl-2palmitoylphosphocholine are reportedly increase in case of both the fungal as well as bacterial infections of host insects (Hoxmeier et al., 2015; Xu et al., 2015). The atypical elevations of the lipid levels thus fulfill the heightened biomolecular demands for energy generations, membrane repair, and signaling pathway intermediates (Atella and Shahabuddin, 2002). Hence, the alterations in the lipid levels may also serve as the potent and generic biomarkers of insect immunity under immune compromised conditions. Similarly, the fatty acids released from triglycerides viz., hexadecenoic acid, heptadecenoic acid, and octadecenoic acid further fulfill the energy demands through $\beta$-oxidation (Athenstaedt and Daum, 2006).

\section{Amino Acids}

The upregulation of amino acid metabolism (asparagine, glutamine, lysine) and transglutaminase activity (amino acid cross links forming target clots) are often corresponded to the enhanced humoral immune response among the infected arthropods (Figure 1) (Bulet et al., 1991; Toubarro et al., 2013). In contrast, the elevation in the levels of the free amino acids in hemocoel might also be attributed to the proteolytic activities of the invading microbial parasites (Harrison and Bonning, 2010). An avant-garde experiment published by Graham et al. (2014) describes the different diet preferences of locusts (Chortoicetes terminifera) subjected to Metarhizium infection in vitro. The authors observed that the locust which switched their feeding to high carbohydrate diets survived the fungal infection more effectively than their counterparts fed upon high protein diets. Hence, a logical conjecture was drawn that the entomopathogenic fungi can more efficiently harness the protein contents from the insect hemocoel than the host themselves, and thus the high mortality was observed among the protein rich diet fed insects. Therefore, the meticulous and more robust metabolomic experimental design is required to differentiate the free amino acids and related metabotypes in hemocoel characterized for their origin while the stages of mycosis.

\section{Eicosanoids}

They are the signaling metabolites produced from the oxygenated poly-unsaturated fatty acids and functionally important for the immune responses in insects (Stanley, 2006). In particular, the insects infected with entomopathogenic fungi are reportedly known to have the reduced levels of eicosanoids viz., 17hydroxyeicosatetraenoic acid (17-HETE) and protaglandins - E2 (PGE2) (Xu et al., 2015). The mechanism seems more pertinent as the suppression of eicosanoids and prostanoids is analogously reported in case of entomopathogenic bacteria and nematode infections thus establishing their vital role in the insect's innate immunity (Hyrsl et al., 2010; Hwang et al., 2013; Hoxmeier et al., 2015).

Additionally, the reduced host immunity can further be implicated based on the upregulation of cytosine (nitrogenous bases) and trimethyluric acid, a purine alkaloid (Xu et al., 2015). Further, Diaz-Albiter et al. (2012) have suggested the deleterious effects of uric acid components on insect's ROS mediated immunity, though the phenomena is quite unclear in case of in vivo metabolome alterations following mycoses. Nonetheless, there are many more esoteric facets of insect immunity besides the intrinsic immune response and metabolomes which needs to be delineated (Box 2). Quintessentially, the relative selection pressure induced by the host-pathogen interaction can thus be called as the main driving force behind the altered insect immunity and adaptation in the challenged environments.

\section{CONCLUSION}

The evolution of recalcitrant pest varieties and increased environmental concerns owing to the use of synthetic chemical pesticides has turned the attempts toward the development of efficacious biopesticides, a non-trivial undertaking. However, the relative progress in the development of efficient biopesticides and their ground formulation are apparently stonewalled on account of our surprisingly limited comprehension of the quasi simplistic biocontrol mechanism. In recent years, a renewed interest has grown among the researchers to delineate the biocontrol mechanisms in more unconventional ways viz., target pest behavior (Shang et al., 2015), de novo genome assemblies for pathotype characterizations (Shang et al., 2016), host-pathogens interaction transcriptomics (Chu et al., 2016), and metabolomics (de Bekker et al., 2013; Xu et al., 2015) etc. Hence, the trophic interactions of the ubiquitously distributed entomopathogenic fungi in diverse environmental habitats can further be envisaged in terms of their altered metabolomes which offers a generic harbinger to address the key bottlenecks of associated biocontrol mechanisms. The trophic interface between entomopathogenic

\section{BOX 2 | The Gordian knot: biocontrol fungi and host insect's interaction metabolomics.}

The metabolites and metabolomes being the most generic cues governing the biological interactions are undoubtedly the most critical factors which govern fungal biocontrol mechanisms. However, our present comprehensions are surprisingly limited regarding perplexes of host insect's co-evolutionary metabolomes and the role of environmental factors in shaping these interactions. The varying efficacy of broad range entomopathogenic fungi toward insects of similar classes further compels us to re-examine our nebular hypothesis regarding the mechanisms of insect mycoses. The modern assumptions credit this differential effectiveness of entomopathogenic fungi to the host insect's co-evolution in the challenged environments through co-interactions with symbiotic microflora which passively confer a protective chemical shield of anti-fungal metabolites or enhanced immune response (Toledo et al., 2011; Eleftherianos et al., 2013). However, it is still unclear about the chemical nature of these metabolites, either of fungal or insect origin, which actually instigates the chain of conflicting events among the interacting species. Additionally, we don't know how these elicitor molecules (metabolites) affect the priming of co-evolutionary multi-trophic interactions among them at genomic platforms? Nonetheless, it can only be assumed that the scarce data and information available thus far represent the tip of the iceberg with limited comprehensions for biocontrol sciences and fungal trophic interactions. 
fungi and corresponding host insects has often been construed for fungal entomotoxins which impairs their targets. However, the proportional immune response conferring immunity in host insects can also be extrapolated for altered metabolism and defense biomarkers viz., PO-mediated melanin synthesis, insect bioenergetics (carbohydrates, fatty acids, and lipid), free amino acids, antimicrobial peptides, and eicosanoids. Additionally, the regulatory networks and signal transduction pathways affected in mycosed host insects could also be probed and correlated with fungi mediated selective perturbations. Hence, a metabolomic insight of the fungal-insect antagonistic interactions could potentially reshape our current strategies to develop the selective, broad target, and hypervirulent entomopathogenic fungal strains. Besides the realms of much touted biocontrol applications, the new facets of entomopathogenic fungi interactions as plant endophyte, rhizopheric colonizer, and soil inhabitant can also be addressed using the newfangled omic-approaches.

\section{REFERENCES}

Aghajanzadeh, S., Mallik, B., and Chandrashekar, S. C. (2006). Toxicity of culture filtrate of hirsutella thompsonii fisher against citrus rust mite, phyllocoptruta oleivora ashmead (acari: eriophyidae) and two spotted spider mite, tetranychus urticae Koch (Acari: Tetranychidae). Int. J. Agric. Biol. 8, 276-279.

Alabouvette, C., Olivain, C., Migheli, Q., and Steinberg, C. (2009). Microbiological control of soil-borne phytopathogenic fungi with special emphasis on wiltinducing Fusarium oxysporum. New Phytol. 184, 529-44. doi: 10.1111/j.14698137.2009.03014.x

Alexopoulos, C. J., and Mims, C. W. (1979). Introductory Mycology, 3rd Edn. New York, NY: John Wiley and sons Inc.

Araújo, J. P., and Hughes, D. P. (2016). Chapter one-diversity of entomopathogenic fungi: which groups conquered the insect Body? Adv. Genet. 94, 1-39.

Ardia, D. R., Gantz, J. E., Brent, C., and Strebel, S. (2012). Costs of immunity in insects: an induced immune response increases metabolic rate and decreases antimicrobial activity. Funct. Ecol. 26, 732-739. doi: 10.1111/j.13652435.2012.01989. $\mathrm{x}$

Arnold, A. E., and Lewis, L. C. (2005). "Ecology and evolution of fungal endophytes, and their roles against insects," in Insect-Fungal Associations: Ecology and Evolution, eds F. E. Vega and M. Blackwell (New York, NY: Oxford University Press), 74-96.

Asaff, A., Cerda-García-Rojas, C., and De la Torre, M. (2005). Isolation of dipicolinic acid as an insecticidal toxin from Paecilomyces fumosoroseus. Appl. Microbiol. Biotechnol. 68, 542-547. doi: 10.1007/s00253-005-1909-2

Atella, G. C., and Shahabuddin, M. (2002). Differential partitioning of maternal fatty acid and phospholipid in neonate mosquito larvae. J. Exp. Biol. 205, 3623-3630.

Athenstaedt, K., and Daum, G. (2006). The life cycle of neutral lipids: synthesis, storage and degradation. Cell. Mol. Life Sci. 63, 1355-1369. doi: 10.1007/s00018006-6016-8

Bandani, A. R. (2004). Effect of entomopathogenic fungus Tolypocladium species metabolite efrapeptin on Galleria mellonella agglutinin. Commun. Agric. Appl. Biol. Sci. 69, 165-169.

Bandani, A. R. (2008). The effects of entomopathogenic fungus, Tolypocladium cylindrosporum on cellular defence system of Galleria mellonella. J. Agric. Sci. Technol. 10, 135-146.

Bandani, A. R., Amiri, B., Butt, T. M., and Gordon-Weeks, R. (2001). Effects of efrapeptin and destruxin, metabolites of entomogenous fungi, on the hydrolytic activity of a vacuolar type ATPase identified on the brush border membrane vesicles of Galleria mellonella midgut and on plant membrane bound hydrolytic enzymes. Biochim. Biophys. Acta - Biomembr. 1510, 367-377. doi: 10.1016/S0005-2736(00)00370-9

Benítez, T., Rincón, A. M., Limón, M. C., and Codón, A. C. (2010). Biocontrol mechanisms of Trichoderma strains. Int. Microbiol. 7, 249-260.

\section{AUTHOR CONTRIBUTIONS}

DS, SS, and CL have made conceptual as well as direct contribution in writing this manuscript.

\section{ACKNOWLEDGMENTS}

This work was supported by the National Research Foundation of Korea (NRF) grant funded by the Korea government (MSIP) (No. NRF-2014R1A2A1A11050884) and by the Strategic Initiative for Microbiomes in Agriculture and Food, Ministry of Agriculture, Food and Rural Affairs, Republic of Korea [as part of the (multi ministerial) Genome Technology to Business Translation Program] (Grant number 916005-2).

Blackwell, M. (2010). Fungal evolution and taxonomy. BioControl 55, 7-16. doi: 10.1007/s10526-009-9243-8

Boguś, M. I., Kêdra, E., Bania, J., Szczepanik, M., Czygier, M., Jabłoñski, P., et al. (2007). Different defense strategies of Dendrolimus pini, Galleria mellonella, and Calliphora vicina against fungal infection. J. Insect Physiol. 53, 909-922. doi: 10.1016/j.jinsphys.2007.02.016

Bulet, P., Cociancich, S., Dimarcq, J. L., Lambert, J., Reichhart, J. M., Hoffmann, D., et al. (1991). Insect immunity. Isolation from a coleopteran insect of a novel inducible antibacterial peptide and of new members of the insect defensin family. J. Biol. Chem. 266, 24520-24525.

Bushley, K. E., Raja, R., Jaiswal, P., Cumbie, J. S., Nonogaki, M., Boyd, A. E., et al. (2013). The genome of Tolypocladium inflatum: evolution, organization, and expression of the cyclosporin biosynthetic gene cluster. PLoS Genet. 9:e1003496. doi: 10.1371/journal.pgen.1003496

Buttachon, S., Chandrapatya, A., Himaman, W., and Kijjoa, A. (2013). Acaricidal activity of Hypocrella raciborskii Zimm. (Hypocreales: Clavicipitaceae) crude extract and some pure compounds on Tetranychus urticae Koch (Acari: Tetranychidae). Afr. J. Microbiol. Res. 7, 557-585. doi: 10.5897/AJMR12.1727

Champlin, F. R., and Grula, E. A. (1979). Noninvolvement of beauvericin in the entomopathogenicity of Beauveria bassiana. Appl. Environ. Microbiol. 37, 1122-1126.

Chu, Z. J., Wang, Y. J., Ying, S. H., Wang, X. W., and Feng, M. G. (2016). Genome-wide host-pathogen interaction unveiled by transcriptomic response of diamondback moth to fungal infection. PLoS ONE 11:e0152908. doi: 10.1371/journal.pone.0152908

Claydon, N., and Grove, J. F. (1982). Insecticidal secondary metabolic products from the entomogenous fungus Verticillium lecanii. J. Invertebr. Pathol. 40, 413-418. doi: 10.1016/0022-2011(82)90180-X

Colegate, S. M., Dorling, P., and Huxtable, C. R. (1979). A spectroscopic investigation of swainsonine: an $\alpha$-mannosidase inhibitor isolated from Swainsona canescens. Aust. J. Chem. 32, 2257-2264. doi: 10.1071/CH9792257

de Bekker, C., Smith, P. B., Patterson, A. D., and Hughes, D. P. (2013). Metabolomics reveals the heterogeneous secretome of two entomopathogenic fungi to ex vivo cultured insect tissues. PLoS ONE 8:e70609. doi: 10.1371/journal.pone.0070609

de Carolina Sánchez-Pérez, L., Barranco-Florido, J. E., Rodríguez-Navarro, S., and Cervantes-Mayagoitia, J. F. (2014). Enzymes of entomopathogenic fungi, advances and insights. Adv. Enzyme Res. 2, 65-76. doi: 10.4236/aer.2014.22007

de Faria, M. R., and Wraight, S. P. (2007). Mycoinsecticides and mycoacaricides: a comprehensive list with worldwide coverage and international classification of formulation types. Biol. Control. 43, 237-256. doi: 10.1016/j.biocontrol.2007.08.001

Diaz-Albiter, H., Sant'Anna, M. R., Genta, F. A., and Dillon, R. J. (2012). Reactive oxygen species-mediated immunity against Leishmania mexicana and Serratia marcescens in the phlebotomine sand fly Lutzomyia longipalpis. J. Biol. Chem. 287, 23995-24003. doi: 10.1074/jbc.M112.376095 
Döll, K., Chatterjee, S., Scheu, S., Karlovsky, P., and Rohlfs, M. (2013). Fungal metabolic plasticity and sexual development mediate induced resistance to arthropod fungivory. Proc. R. Soc. Lond. B Biol. Sci. 280:20131219. doi: 10.1098/rspb.2013.1219

Dubovskiy, I. M., Whitten, M. M. A., Kryukov, V. Y., Yaroslavtseva, O. N., Grizanova, E. V., Greig, C., et al. (2013). More than a colour change: insect melanism, disease resistance and fecundity. Proc. R. Soc. Lond. B Biol. Sci. 280:20130584. doi: 10.1098/rspb.2013.0584

Dumas, C., Matha, V., Quiot, J. M., and Vey, A. (1996). Effects of destruxins, cyclic depsipeptide mycotoxins, on calcium balance and phosphorylation of intracellular proteins in lepidopteran cell lines. Comp. Biochem. Physiol. C Toxicol. Pharmacol. 114, 213-219. doi: 10.1016/0742-8413(96)00041-2

Elbein, A. D., Solf, R., Dorling, P. R., and Vosbeck, K. (1981). Swainsonine: an inhibitor of glycoprotein processing. Proc. Natl. Acad. Sci. U.S.A. 78, 7393-7397. doi: $10.1073 /$ pnas.78.12.7393

Eleftherianos, I., Atri, J., Accetta, J., and Castillo, J. (2013). Endosymbiotic bacteria in insects: guardians of the immune system? Front. Physiol. 4:46. doi: 10.3389/fphys.2013.00046

Elsworth, J. F., and Grove, J. F. (1977). Cyclodepsipeptides from Beauveria bassiana Bals. Part 1. Beauverolides H and I. J. Chem. Soc. Perkin Trans. 1, 207-273. doi: 10.1039/P19770000270

Feng, P., Shang, Y., Cen, K., and Wang, C. (2015). Fungal biosynthesis of the bibenzoquinone oosporein to evade insect immunity. Proc. Natl. Acad. Sci. U.S.A. 112, 11365-11370. doi: 10.1073/pnas.1503200112

Fiolka, M. J. (2008). Immunosuppressive effect of cyclosporin A on insect humoral immune response. J. Invertebr. Pathol. 98, 287-292. doi: 10.1016/j.jip.2008.03.015

Fuchs, S., Behrends, V., Bundy, J. G., Crisanti, A., and Nolan, T. (2014). Phenylalanine metabolism regulates reproduction and parasite melanization in the malaria mosquito. PLoS ONE 9:e84865. doi: 10.1371/journal.pone.0084865

Glare, T. R., and Milner, R. J. (1991). "Ecology of entomopathogenic fungi," in Handbook of Applied Mycology, eds D. K. Arora, K. G. Mukeriji, and J. E. F. Pugh (New York, NY: Dekker), 547-612.

Glenn, A. E., Zitomer, N. C., Zimeri, A. M., Williams, L. D., Riley, R. T., and Proctor, R. H. (2008). Transformation-mediated complementation of a FUM gene cluster deletion in Fusarium verticillioides restores both fumonisin production and pathogenicity on maize seedlings. Mol. Plant Microbe Interact. 21, 87-97. doi: 10.1094/MPMI-21-1-0087

Goettel, M. S., Hajek, A. E., Siegel, J. P., and Evans, H. C. (2001). "Safety of fungal biocontrol agents," in Fungi as Biocontrol Agents, Progress, Problems, and Potential, eds T. M. Butt, C. W. Jackson, N. Magan (Wallingford, CT: CAB International), 347-375.

Graham, R. I., Deacutis, J. M., Pulpitel, T., Ponton, F., Simpson, S. J., and Wilson, K. (2014). Locusts increase carbohydrate consumption to protect against a fungal biopesticide. J. Insect Physiol. 69, 27-34. doi: 10.1016/j.jinsphys.2014.05.015

Grove, J. F., and Pople, M. (1980). The insecticidal activity of beauvericin and the enniatin complex. Mycopathologia 70, 103-105. doi: 10.1007/BF00443075

Gupta, S., Krasnoff, S. B., Roberts, D. W., Renwick, J. A. A., Brinen, L. S., and Clardy, J. (1992). Structure of efrapeptins from the fungus Tolypocladium niveum: peptide inhibitors of mitochondrial ATPase. J. Org. Chem. 57, 23062313. doi: $10.1021 /$ jo00034a022

Gupta, S., Krasnoff, S. B., Underwood, N. L., Renwick, J. A. A., and Roberts, D. W. (1991). Isolation of beauvericin as an insect toxin from Fusarium semitectum and Fusarium moniliforme var. subglutinans. Mycopathologia 115, 185-189. doi: 10.1007/BF00462223

Gupta, S., Roberts, D. W., and Renwick, J. A. A. (1989). Insecticidal cyclodepsipeptides from Metarhizium anisopliae. J. Chem. Soc. Perkin Trans. 1, 2347-2357. doi: 10.1039/P19890002347

Hajek, A. E. (1997). "Ecology of terrestrial fungal entomopathogens," in Advances in Microbial Ecology, ed. J. G. Jones (New York, NY: Springer), 193-249.

Hallmon, C. F., Schreiber, E. T., Vo, T., and Bloomquist, A. (2000). Field trials of three concentrations of Laginex as biological larvicide compared to Vectobac$12 \mathrm{AS}$ as a biocontrol agent for Culex quinquefasciatus. J. Amer. Mosq. Control Assoc. 16, 5-8.

Hamill, R. L., Higgens, C. E., Boaz, H. E., and Gorman, M. (1969). The structure of beauvericin, a new depsipeptide antibiotic toxic to Artemia salina. Tetrahedron Lett. 10, 4255-4258. doi: 10.1016/S0040-4039(01)88668-8
Harrison, R. L., and Bonning, B. C. (2010). Proteases as insecticidal agents. Toxins 2, 935-953. doi: 10.3390/toxins2050935

Hinaje, M., Ford, M., Banting, L., Arkle, S., and Khambay, B. (2002). An investigation of the ionophoric characteristics of destruxin A. Arch. Biochem. Biophys. 405, 73-77. doi: 10.1016/S0003-9861(02)00275-8

Hino, M., Nakayama, O., Tsurumi, Y., Adachi, K., Shibata, T., Terano, H., et al. (1985). Studies of an immunomodulator, swainsonine. I. Enhancement of immune response by swainsonine in vitro. J. Antibiot. 38, 926-935. doi: 10.7164/antibiotics.38.926

Hoxmeier, J. C., Thompson, B. D., Broeckling, C. D., Small, P., Foy, B. D., Prenni, J., et al. (2015). Analysis of the metabolome of Anopheles gambiae mosquito after exposure to Mycobacterium ulcerans. Sci. Rep. 5:9242. doi: 10.1038/srep09242

Hudson, H. J. (1986). "Fungi as decomposers of wood," in Fungal Biology, eds A. J. Willis and M. A. Sleigh (London: Edward Arnold Publishers Ltd), 84-109.

Humber, R. A. (2012). Entomophthoromycota: a new phylum and reclassification for entomophthoroid fungi. Mycotaxon 120, 477-492. doi: 10.5248/120.477

Hwang, J., Park, Y., Kim, Y., and Lee, D. (2013). An entomopathogenic bacterium, Xenorhabdus nematophila, suppresses expression of antimicrobial peptides controlled by Toll and Imd pathways by blocking eicosanoid biosynthesis. Arch. Insect Biochem. Physiol. 83, 151-169. doi: 10.1002/arch.21103

Hyrsl, P., Dobes, P., Wang, Z., Hauling, T., Wilhelmsson, C., and Theopold, U. (2010). Clotting factors and eicosanoids protect against nematode infections. J. Innate Immune. 3, 73-77. doi: 10.1159/issn.1662-811X

Isaka, M., Kittakoop, P., and Thebtaranonth, Y. (2003). "Secondary metabolites of Clavicipitalean fungi," in Clavicipitalean fungi: Evolutionary Biology, Chemistry, Biocontrol, and culture impacts (Mycology Series), eds J. F. White, C. W. Bacon, N. L. Hywel-Jones, and J. W. Spatafora (Boca Raton, FL: CRC Press), 355-398.

Isaka, M., Palasarn, S., Tobwor, P., Boonruangprapa, T., and Tasanathai, K. (2012). Bioactive anthraquinone dimers from the leafhopper pathogenic fungus Torrubiella sp. BCC 28517. J. Antibiot. 65, 571-574. doi: 10.1038/ja.2012.76

Isaka, M., Yangchum, A., Rachtawee, P., Komwijit, S., and Lutthisungneon, A. (2010). Hopane-type triterpenes and binaphthopyrones from the scale insect pathogenic fungus Aschersonia paraphysata BCC 11964. J. Nat. Prod. 73, 688692. doi: 10.1021/np1000363

Jeffs, L. B., and Khachatourians, G. G. (1997). Toxic properties of Beauveria pigments on erythrocyte membranes. Toxicon 35, 1351-1356. doi: 10.1016/S0041-0101(97)00025-1

Jestoi, M. (2008). Emerging Fusarium-mycotoxins fusaproliferin, beauvericin, enniatins, and moniliformin-A review. Crit. Rev. Food Sci. Nutr. 48, 21-49. doi: $10.1080 / 10408390601062021$

Jin-Ming, G. (2006). New biologically active metabolites from Chinese higher fungi. Curr. Org. Chem. 10, 849-871. doi: 10.2174/138527206776894393

Kan, H., Kim, C. H., Kwon, H. M., Park, J. W., Roh, K. B., Lee, H., et al. (2008). Molecular control of phenoloxidase-induced melanin synthesis in an insect. J. Biol. Chem. 283, 25316-25323. doi: 10.1074/jbc.M804364200

Kanaoka, M., Isogai, A., Murakoshi, S., Ichinoe, M., Suzuki, A., and Tamura, S. (1978). Bassianolide, a new insecticidal cyclodepsipeptide from Beauveria bassiana and Verticillium lecanii. Agric. Biol. Chem. 42, 629-635. doi: 10.1080/00021369.1978.10863029

Kanehisa, M., and Goto, S. (2000). KEGG: kyoto encyclopedia of genes and genomes. Nucleic Acids Res. 28, 27-30. doi: 10.1093/nar/28.1.27

Karling, J. S. (1948). Chytridiosis of scale insects. Am. J. Bot. 35, 246-254. doi: $10.2307 / 2437955$

Karlovsky, P. (2008). "Secondary metabolites in soil ecology," in Secondary Metabolites in Soil Ecology, ed. P. Karlovsky (Berlin: Springer), 1-19.

Keller, S., Kessler, P., and Schweizer, C. (2003). Distribution of insect pathogenic soil fungi in Switzerland with special reference to Beauveria brongniartii and Metarhizium anisopliae. Biocontrol. 48, 307-319. doi: 10.1023/A:1023646207455

Keller, S., and Zimmermann, G. (1989). "Mycopathogens of soil insects," in InsectFungus Interactions, eds N. Wilding, N. M. Collins, P. M. Hammond, and J. F. Webber (Cambridge, MA: Academic Press), 239-270.

Kempken, F., and Rohlfs, M. (2010). Fungal secondary metabolite biosynthesis-a chemical defence strategy against antagonistic animals? Fungal Ecol. 3, 107-114. doi: 10.1016/j.funeco.2009.08.001

Kerwin, J. L., Dritz, D. A., and Washino, R. K. (1994). Pilot scale production and application in wildlife ponds of Lagenidium giganteum (Oomycetes: Lagenidiales). J. Amer. Mosq. Control Assoc. 10, 451-455. 
Kim, J. R., Yeon, S. H., Kim, H. S., and Ahn, Y. J. (2002). Larvicidal activity against Plutella xylostella of cordycepin from the fruiting body of Cordyceps militaris. Pest Manag. Sci. 58, 713-717. doi: 10.1002/ps.508

Kim, S. K. (2011). Re description of Simulium (Simulium) japonicum (Diptera: Simuliiae) and its entomopathogenic fungal symbionts. Entomol. Res. 41, 208210. doi: $10.1111 /$ j.1748-5967.2011.00336.x

Kleinkauf, H., and von Döhren, H. (1987). Biosynthesis of peptide antibiotics. Ann. Rev. Microbiol. 41, 259-289. doi: 10.1146/annurev.mi.41.100187.001355

Kleinkauf, H., and von Döhren, H. (1990). "Review: nonribosomal biosynthesis of peptide antibiotics”. in EJB Reviews eds P. Christen, E. Hofmann and Federation of European Biochemical Societies (Berlin: Springer), 151-165.

Kryukov, V. I. U., Yaroslavtseva, O. N., Dubovskiy, I. M., Tyurin, M. V., Kryukova, N. A., and Glupov, V. V. (2014). Insecticidal and immunosuppressive effect of ascomycete Cordyceps militaris on the larvae of the Colorado potato beetle Leptinotarsa decemlineata. Biol. Bulletin 41, 3. doi: 10.1134/S1062359014020046

Kulkarni, M. M., Karafova, A., Kamysz, W., Schenkman, S., Pelle, R., and McGwire, B. S. (2013). Secreted trypanosome cyclophilin inactivates lytic insect defense peptides and induces parasite calcineurin activation and infectivity. J. Biol. Chem. 288, 8772-8784. doi: 10.1074/jbc.M112.421057

Lastra, C. L., Scorsetti, A. C., Marti, G. A., and García, J. J. (2004). Host range and specificity of an Argentinean isolate of the aquatic fungus Leptolegnia chapmanii (Oomycetes: Saprolegniales), a pathogen of mosquito larvae (Diptera: Culicidae). Mycopathologia. 158, 311-315. doi: 10.1007/s11046005-0498-Z

Li, Z., Xu, X., Huang, Y., Ding, L., Wang, Z., Yu, G., et al. (2012). Swainsonine activates mitochondria-mediated apoptotic pathway in human lung cancer A549 cells and retards the growth of lung cancer xenografts. Int. J. Biol. Sci. 8, 394-405. doi: 10.7150/ijbs.3882

Lobo, L. S., Luz, C., Fernandes, ÉK., Juárez, M. P., and Pedrini, N. (2015). Assessing gene expression during pathogenesis: Use of qRT-PCR to follow toxin production in the entomopathogenic fungus Beauveria bassiana during infection and immune response of the insect host Triatoma infestans. J. Invertebr. Pathol. 128, 14-21. doi: 10.1016/j.jip.2015.04.004

Martin, L. B., Weil, Z. M., and Nelson, R. J. (2008). Seasonal changes in vertebrate immune activity: mediation by physiological trade-offs. Philos. Trans. R. Soc. Lond. B Biol. Sci. 363, 321-339. doi: 10.1098/rstb.2007.2142

McCoy, C. W., Omoto, C., Mazet, I., and Vey, A. (1992). "Biological activity of crude filtrates and hirsutellin A to mosquitoes and phytophagous arthropods," in Proceedings of the Abstracts 120 XXV Annual Meeting (Heidelberg: Society of Invertebrate Pathology).

McInnes, A. G., Smith, D. G., Wat, C. K., Vining, L. C., and Wright, J. L. (1974). Tenellin and bassianin, metabolites of beauveria species. Structure elucidation with $15 \mathrm{~N}$-and doubly $13 \mathrm{C}$-enriched compounds using $13 \mathrm{C}$ nuclear magnetic resonance spectroscopy. J. Chem. Soc. Chem. Commun. 8, 281-282. doi: 10.1039/c39740000281

Meng, X., Hu, J., Xu, X., Wang, Z., Hu, Q., Jin, F., et al. (2013). Toxic effect of destruxin A on abnormal wing disc-like (SLAWD) in Spodoptera litura fabricius (Lepidoptera: Noctuidae). PLoS ONE 8:e57213. doi: 10.1371/journal.pone.0057213

Meyling, N. V., and Eilenberg, J. (2006). Occurrence and distribution of soil borne entomopathogenic fungi within a single organic agroecosystem. Agric. Ecosys. Environ. 113, 336-341. doi: 10.1016/j.agee.2005.10.011

Milner, R. J. (1997). Prospects for biopesticides for aphid control. Entomophaga 42:227. doi: 10.1007/BF02769900

Molnár, I., Gibson, D. M., and Krasnoff, S. B. (2010). Secondary metabolites from entomopathogenic Hypocrealean fungi. Nat. Prod. Rep. 27, 1241-1275. doi: 10.1039/C001459C

Molyneux, R. J., and James, L. F. (1982). Loco intoxication: indolizidine alkaloids of spotted locoweed (Astragalus lentiginosus). Science 216, 190-191. doi: $10.1126 /$ science. 6801763

Nakajyo, S., Shimizu, K., Kometani, A., Suzuki, A., Ozaki, H., and Urakawa, N. (1983). On the inhibitory mechanism of bassianolide, a cyclodepsipeptide, in acetylcholine-induced contraction in guinea-pig taenia coli. Jpn. J. Pharmacol. 33, 573-582. doi: 10.1254/jjp.33.573

Nappi, A., Poirié, M., and Carton, Y. (2009). "the role of melanization and cytotoxic by-products in the cellular immune responses of drosophila against parasitic wasps," in Advances in Parasitology, eds D. Rollinson and S. I. Hay (Cambridge, MA: Academic Press), 99-121.
Narladkar, B. W., Shivpuje, P. R., and Harke, P. C. (2015). Fungal biological control agents for integrated management of Culicoides spp. (Diptera: Ceratopogonidae) of livestock. Vet. World. 8, 2. doi: 10.14202/vetworld.2015.156-163

Onofre, S. B., Riveros Gonzalez, R., Messias, C. L., Azevedo, J. L., and Barros, N. M. D. (2002). LC50 of the peptide produced by the entomopathogenic fungus Nomuraea rileyi (Farlow) Samson active against third instar larvae of Anticarsia gemmatalis (Lep.: Noctuidae). Braz. Arch. Biol. Technol. 45, 156-163. doi: 10.1590/S1516-89132002000300004

Ortiz-Urquiza, A., and Keyhani, N. O. (2013). Action on the surface: entomopathogenic fungi versus the insect cuticle. Insects 4, 357-374. doi: 10.3390/insects 4030357

Ownley, B. H., Gwinn, K. D., and Vega, F. E. (2009). "Endophytic fungal entomopathogens with activity against plant pathogens: ecology and evolution," in The Ecology of Fungal Entomopathogens, eds V. C. Verma and A. C. Gange (Dordrecht: Springer), 113-128.

Pal, S., Leger, R. J. S., and Wu, L. P. (2007). Fungal peptide Destruxin A plays a specific role in suppressing the innate immune response in Drosophila melanogaster. J. Biol. Chem. 282, 8969-8977. doi: 10.1074/jbc.M605927200

Pedras, M. S. C., Zaharia, L. I., and Ward, D. E. (2002). The destruxins: synthesis, biosynthesis, biotransformation, and biological activity. Phytochemistry 59, 579-596. doi: 10.1016/S0031-9422(02)00016-X

Pedrini, N., Ortiz-Urquiza, A., Huarte-Bonnet, C., Fan, Y., Juárez, M. P., and Keyhani, N. O. (2015). Tenebrionid secretions and a fungal benzoquinone oxidoreductase form competing components of an arms race between a host and pathogen. Proc. Natl. Acad. Sci. U.S.A. 112, E3651-E3660. doi: 10.1073/pnas. 1504552112

Pelizza, S. A., Lopez Lastra, C. C., Becnel, J. J., Bisaro, V., and Garcia, J. J. (2007). Biotic and abiotic factors affecting Leptolegnia chapmanii infection in Aedes aegypti. J. Amer. Mosq. Control Assoc. 23, 177-181. doi: 10.2987/8756971X(2007)23[177:BAAFAL]2.0.CO;2

Pelizza, S. A., Scorsetti, A. C., and Tranchida, M. C. (2013). The sublethal effects of the entomopathic fungus Leptolegnia chapmanii on some biological parameters of the dengue vector Aedes aegypti. J. Insect Sci. 13, 22. doi: 10.1673/031.013.2201

Pell, J. K., Eilenberg, J., Hajek, A. E., and Steinkraus, D. C. (2001). “Biology, ecology and pest management potential of Entomophthorales," in Fungi as Biocontrol Agents: Progress, Problems and Potential, eds T. M. Butt, et al. (Wallingford, CT: CAB International), 71-153.

Podsiadlowski, L., Matha, V., and Vilcinskas, A. (1998). Detection of a P-glycoprotein related pump in Chironomus larvae and its inhibition by verapamil and cyclosporin A. Comp. Biochem. Physiol. B Biochem. Mol. Biol. 121, 443-450. doi: 10.1016/S0305-0491(98)10137-2

Porras-Alfaro, A., and Bayman, P. (2011). Hidden fungi, emergent properties: endophytes and microbiomes. Phytopathology 49, 291-315. doi: 10.1146/annurev-phyto-080508-081831

Prompiboon, P., Bhumiratana, A., Ruchirawat, S., Boucias, D. G., and Wiwat, C. (2008). Isolation of ergosterol peroxide from Nomuraea rileyi infected larvae of tobacco cutworm. World J. Microbiol. Biotechnol. 24:2909. doi: 10.1007/s11274008-9830-3

Quarles, W. (2013). New biopesticides for IPM and organic production. IPM Pract. $33,1-20$.

Quesada-Moraga, E., Navas-Cortés, J. A., Maranhao, E. A., Ortiz-Urquiza, A., and Santiago-Álvarez, C. (2007). Factors affecting the occurrence and distribution of entomopathogenic fungi in natural and cultivated soils. Mycol. Res. 111(Pt. 8), 947-966. doi: 10.1016/j.mycres.2007.06.006

Roberts, D. W., Fuxa, J. R., Gaugler, R., Goettel, M., Jaques, R., and Maddox, J. (1991). "Use of pathogens in insect control," in Handbook of Pest Management in Agriculture, ed. D. Pimentel (Boca Raton, FL: CRC Press), 243-278.

Rohlfs, M., and Churchill, A. C. (2011). Fungal secondary metabolites as modulators of interactions with insects and other arthropods. Fungal Genet. Biol. 48, 23-34. doi: 10.1016/j.fgb.2010.08.008

Rohlfs, M., and Obmann, B. (2009). Species-specific responses of dew fly larvae to mycotoxins. Mycotox. Res. 25, 103-112. doi: 10.1007/s12550-009-0015-1

Roy, H. E., Steinkraus, D. C., Eilenberg, J., Hajek, A. E., and Pell, J. K. (2006). Bizarre interactions and endgames: entomopathogenic fungi and their arthropod hosts. Annu. Rev. Entomol. 51, 331-357. doi: 10.1146/annurev.ento.51.110104. 150941 
Samuels, R. I., Charnley, A. K., and Reynolds, S. E. (1988). Calcium channel activation of insect muscle by destruxins, insecticidal compounds produced by Metarhizium anisopliae. Comp. Biochem. Physiol. C Toxicol. Pharmacol. 90, 403-412. doi: 10.1016/0742-8413(88)90018-7

Schardl, C. L. (2001). Plant Defences Against Herbivore and Insect Attack. Hoboken, NJ: John Wiley \& Sons, Inc.

Schneider, M. J., Ungemach, F. S., Broquist, H. P., and Harris, T. M. (1983). (1S, 2R, 8R, 8aR)-1, 2, 8-trihydroxyoctahydroindolizine (swainsonine), an $\alpha$-mannosidase inhibitor from Rhizoctonia leguminicola. Tetrahedron 39, 29 32. doi: 10.1016/S0040-4020(01)97625-2

Setlow, B., Atluri, S., Kitchel, R., Koziol-Dube, K., and Setlow, P. (2006). Role of dipicolinic acid in resistance and stability of spores of Bacillus subtilis with or without DNA-protective $\alpha / \beta$-type small acid-soluble proteins. J. Bacteriol. 188, 3740-3747 doi: 10.1128/JB.00212-06

Shang, Y., Feng, P., and Wang, C. (2015). Fungi that infect insects: altering host behaviour and beyond. PLoS Pathog. 11:e1005037. doi: 10.1371/journal.ppat.1005037

Shang, Y., Xiao, G., Zheng, P., Cen, K., Zhan, S., and Wang, C. (2016). Divergent and convergent evolution of fungal pathogenicity. Genome Biol. Evol. 8, 13741387. doi: $10.1093 / \mathrm{gbe} / \mathrm{evw} 082$

Sheridan, K. J., Dolan, S. K., and Doyle, S. (2015). Endogenous cross-talk of fungal metabolites. Front. Microbiol. 5:732. doi: 10.3389/fmicb.2014.00732

Singh, D., and Kaur, G. (2014a). Production, HPLC analysis, and in situ apoptotic activities of swainsonine toward lepidopteran, Sf-21 cell line. Biotechnol. Prog. 30, 1196-205. doi: 10.1002/btpr.1943

Singh, D., and Kaur, G. (2014b). The antileukaemic cell cycle regulatory activities of swainsonine purified from Metarhizium anisopliae fermentation broth. Nat. Prod. Res. 28, 2044-2047. doi: 10.1080/14786419.2014.919287

Skrobek, A., Shah, F. A., and Butt, T. M. (2008). Destruxin production by the entomogenous fungus Metarhizium anisopliae in insects and factors influencing their degradation. Biocontrol 53, 361-373. doi: 10.1007/s10526-007-9077-1

Smilanich, A. M., Dyer, L. A., and Gentry, G. L. (2009). The insect immune response and other putative defenses as effective predictors of parasitism. Ecology 90, 1434-1440. doi: 10.1890/08-1906.1

Sowjanya Sree, K., Padmaja, V., and Murthy, Y. L. (2008). Insecticidal activity of destruxin, a mycotoxin from Metarhizium anisopliae (Hypocreales), against Spodoptera litura (Lepidoptera: Noctuidae) larval stages. Pest Manag. Sci. 64, 119-125. doi: 10.1002/ps.1480

Stanley, D. (2006). Prostaglandins and other eicosanoids in insects: biological significance. Annu. Rev. Entomol. 51, 25-44. doi: 10.1146/annurev.ento.51.110104.151021

Strasser, H., Vey, A., and Butt, T. M. (2000). Are there any risks in using entomopathogenic fungi for pest control, with particular reference to the bioactive metabolites of Metarhizium, Tolypocladium and Beauveria species? Biocontrol Sci. Technol. 10, 717-735. doi: 10.1080/09583150020011690

Su, X., Zou, F., Guo, Q., Huang, J., and Chen, T. X. (2001). A report on a mosquito-killing fungus. Pythium carolinianum. Fungal Divers. 7, 129-133.

Sun, J. Y., Yang, H., Miao, S., Li, J. P., Wang, S. W., Zhu, M. Z., et al. (2009). Suppressive effects of swainsonine on C6 glioma cell in vitro and in vivo. Phytomedicine 16, 1070-1074. doi: 10.1016/j.phymed.2009.02.012

Suzuki, A., Kanaoka, M., Isogai, A., Tamura, S., Murakoshi, S., and Ichinoe, M. (1977). Bassianolide, a new insecticidal cyclodepsipeptide from Beauveria bassiana and Verticillium lecanii. Tetrahedron Lett. 18, 2167-2170. doi: 10.1016/S0040-4039(01)83709-6

Tang, C. Y., Chen, Y. W., Jow, G. M., Chou, C. J., and Jeng, C. J. (2005). Beauvericin activates $\mathrm{Ca} 2+$-activated $\mathrm{Cl}$-currents and induces cell deaths in Xenopus oocytes via influx of extracellular Ca2+. Chem. Res. Toxicol. 18, 825-833. doi: 10.1021/tx049733d

Toledo, A. V., Alippi, A. M., and de Remes Lenicov, A. M. M. (2011). Growth inhibition of Beauveria bassiana by bacteria isolated from the cuticular surface of the corn leafhopper, Dalbulus maidis and the planthopper, Delphacodes kuscheli, two important vectors of maize pathogens. J. Insect Sci. 11:29. doi: 10.1673/031.011.0129

Toledo, J., Liedo, P., Flores, S., Campos, S. E., Villaseñor, A., et al. (2008). "Use of Beauveria bassiana and Metarhizium anisopliae for fruit fly control: a novel approach." in Proceedings of 7th International Symposium on Fruit Flies of Economic Importance, Salvador, 127-132.

Tonshin, A. A., Teplova, V. V., Andersson, M. A., and Salkinoja-Salonen, M. S. (2010). The Fusarium mycotoxins enniatins and beauvericin cause mitochondrial dysfunction by affecting the mitochondrial volume regulation, oxidative phosphorylation and ion homeostasis. Toxicology 276, 49-57. doi: 10.1016/j.tox.2010.07.001

Toubarro, D., Avila, M. M., Hao, Y., Balasubramanian, N., Jing, Y., Montiel, R., et al. (2013). A serpin released by an entomopathogen impairs clot formation in insect defense system. PLoS ONE 8:7. doi: 10.1371/journal.pone.0069161

Tripathi, S., Kamal, S., Sheramati, I., Oelmuller, R., and Varma, A. (2008). "Mycorrhizal fungi and other root endophytes as biocontrol agents against root pathogens," in Mycorrhiza, ed. A. Varma (Berlin: Springer), 281-306.

Turner, G. (2000). Exploitation of fungal secondary metabolites old and new. Microbiol. Today 27, 118-121.

Uma Devi, K., Padmavathi, J., Uma Maheswara Rao, C., Khan, A. A. P., and Mohan, M. C. (2008). A study of host specificity in the entomopathogenic fungus Beauveria bassiana (Hypocreales, Clavicipitaceae). Biocontrol Sci. Technol. 18:975. doi: 10.1080/09583150802450451

Utermark, J., and Karlovsky, P. (2007). Role of zearalenone lactonase in protection of Gliocladium roseum from fungitoxic effects of the mycotoxin zearalenone. Appl. Environ. Microbiol. 73, 637-642. doi: 10.1128/AEM.01440-06

Vega, F. E., Goettel, M. S., Blackwell, M., Chandler, D., Jackson, M. A., Keller, S., et al. (2009). Fungal entomopathogens: new insights on their ecology. Fungal Ecol. 2, 149-159. doi: 10.1016/j.funeco.2009.05.001

Vega, F. E., Meyling, N. V., Luangsa-Ard, J. J., and Blackwell, M. (2012). "Fungal entomopathogens," in Insect Pathology, 2nd Edn, eds F. Vega and H. K. Kaya (San Diego, CA: Academic Press), 171-220.

Vey, A., Hoagland, R., and Butt, T. M. (2001). "Toxic metabolites of fungal biocontrol agents," in Fungi as Biocontrol Agents: Progress, Problems, and Potential, eds T. M. Butt, et al. (Wallingford, CT: CAB International), 311-346.

Vilmos, P., and Kurucz, E. (1998). Insect immunity: evolutionary roots of the mammalian innate immune system. Immunol. Lett. 62, 59-66. doi: 10.1016/S0165-2478(98)00023-6

Vining, L. C., Kelleher, W. J., and Schwarting, A. E. (1962). Oosporein production by a strain of Beauveria bassiana originally identified as Amanita muscaria. Can. J. Microbiol. 8, 931-933. doi: 10.1139/m62-122

Vyas, N., Dua, K. K., and Prakash, S. (2007). Efficacy of Lagenidium giganteum metabolites on mosquito larvae with reference to nontarget organisms. Parasitol. Res. 101, 385-390. doi: 10.1007/s00436-007-0496-9

Wang, Q., and Xu, L. (2012). Beauvericin, a bioactive compound produced by fungi: a short review. Molecules 17, 2367-2377. doi: 10.3390/molecules170 32367

Weiser, J., and Matha, V. (1988). Tolypin, a new insecticidal metabolite of fungi of the genus Tolypocladium. J. Invertebr. Pathol. 51, 94-96. doi: 10.1016/00222011(88)90093-6

Wiemann, P., and Keller, N. P. (2014). Strategies for mining fungal natural products. J. Ind. Microbial. Biotechnol. 41, 301-313. doi: 10.1007/s10295-0131366-3

Xiao, G., Ying, S. H., Zheng, P., Wang, Z. L., Zhang, S., Xie, X. Q., et al. (2012). Genomic perspectives on the evolution of fungal entomopathogenicity in Beauveria bassiana. Sci. Rep. 2, 483. doi: 10.1038/srep00483

Xu, Y., Orozco, R., Wijeratne, E. K., Espinosa-Artiles, P., Gunatilaka, A. L., Stock, S. P., et al. (2009). Biosynthesis of the cyclooligomer depsipeptide bassianolide, an insecticidal virulence factor of Beauveria bassiana. Fungal Genet. Biol. 46, 353-364. doi: 10.1016/j.fgb.2009.03.001

Xu, Y. J., Luo, F., Gao, Q., Shang, Y., and Wang, C. (2015). Metabolomics reveals insect metabolic responses associated with fungal infection. Anal. Bioanal. Chem. 407, 4815-4821. doi: 10.1007/s00216-015-8648-8

Zimmermann, G. (2007). Review on safety of the entomopathogenic fungi Beauveria bassiana and Beauveria brongniartii. Biocontrol Sci. Technol. 17, 553-596. doi: 10.1080/09583150701309006

Conflict of Interest Statement: The authors declare that the research was conducted in the absence of any commercial or financial relationships that could be construed as a potential conflict of interest.

Copyright (c) 2016 Singh, Son and Lee. This is an open-access article distributed under the terms of the Creative Commons Attribution License (CC BY). The use, distribution or reproduction in other forums is permitted, provided the original author(s) or licensor are credited and that the original publication in this journal is cited, in accordance with accepted academic practice. No use, distribution or reproduction is permitted which does not comply with these terms. 